IZA DP No. 8861

Joint Retirement of Couples:

Evidence from a Natural Experiment

Hans Bloemen

Stefan Hochguertel

Jochem Zweerink

February 2015 


\title{
Joint Retirement of Couples: Evidence from a Natural Experiment
}

\author{
Hans Bloemen \\ VU University Amsterdam, \\ Tinbergen Institute, Netspar and IZA \\ Stefan Hochguertel \\ VU University Amsterdam, \\ Tinbergen Institute and Netspar \\ Jochem Zweerink \\ Utrecht University
}

\section{Discussion Paper No. 8861 \\ February 2015}

\author{
IZA \\ P.O. Box 7240 \\ 53072 Bonn \\ Germany \\ Phone: +49-228-3894-0 \\ Fax: +49-228-3894-180 \\ E-mail: iza@iza.org
}

Any opinions expressed here are those of the author(s) and not those of IZA. Research published in this series may include views on policy, but the institute itself takes no institutional policy positions. The IZA research network is committed to the IZA Guiding Principles of Research Integrity.

The Institute for the Study of Labor (IZA) in Bonn is a local and virtual international research center and a place of communication between science, politics and business. IZA is an independent nonprofit organization supported by Deutsche Post Foundation. The center is associated with the University of Bonn and offers a stimulating research environment through its international network, workshops and conferences, data service, project support, research visits and doctoral program. IZA engages in (i) original and internationally competitive research in all fields of labor economics, (ii) development of policy concepts, and (iii) dissemination of research results and concepts to the interested public.

IZA Discussion Papers often represent preliminary work and are circulated to encourage discussion. Citation of such a paper should account for its provisional character. A revised version may be available directly from the author. 
IZA Discussion Paper No. 8861

February 2015

\section{ABSTRACT}

\section{Joint Retirement of Couples: Evidence from a Natural Experiment}

We estimate and explain the impact of early retirement of husbands on their wives' probability to retire within one year, using administrative micro panel data that cover the whole Dutch population. We employ an instrumental variable approach in which the retirement choice of husbands is instrumented with eligibility rules for generous early retirement benefits that were temporarily and unexpectedly available to them. We find that early retirement opportunities of husbands increased the wives' probability to retire by 24.6 percentage points. This is a strong, and robust effect. Partly, wives respond to husbands' choices at ages when they are themselves likely eligible for early retirement programs.

JEL Classification: $\quad$ C26, J26, J12, J14

Keywords: instruments, retirement, couples

Corresponding author:

Jochem Zweerink

Utrecht School of Economics

Faculty of Law, Economics and Governance

Utrecht University

Kriekenpitplein 21-22

3584 EC Utrecht

The Netherlands

E-mail: j.r.zweerink@uu.nl.

\footnotetext{
" This paper is part of the Netspar research theme "Pensions, savings and retirement decisions (II)," subproject "Retirement decisions: financial incentives, wealth and flexibility". We thank Marianna Brunetti, Adriaan Kalwij and seminar audiences of the "Pensions, retirement, and the financial position of the elderly" theme meeting of Netspar, the International Pension Workshop of Netspar, the $3^{\text {rd }}$ IZA@DC Young Scholar Program and the City University of New York (CUNY) Graduate Centre for helpful and constructive comments.
} 


\section{Introduction}

Large changes across OECD countries are being observed in terms of labor force participation of older workers and retirement patterns. In particular, older workers retire later now than they used to in previous decades, although strong inter-country differences remain (Schirle, 2008; Blundell et al., 2013). These changing patterns have partly been ascribed to changes in institutions such as restricted access to early retirement (ER). Understanding the way individuals make labor supply and retirement decisions is crucial for designing effective policies that are meant to change behavior. Traditional microeconomic retirement models that can guide policy makers in policy choice typically focus on individual decisions in isolation and study the decision process as a function of age, income, health, wealth, and financial or tax incentives (Gustman and Steinmeier (1986), Berkovec and Stern (1991), Lumsdaine, Stock and Wise (1992) and Rust and Phelan (1997)). As a recent strand of literature has emphasized, however, important spillover effects can plausibly be at work when household labor supply and retirement choices are being considered because spousal decisions depend on each other in various ways. Ignoring such effects may have direct implications for the evaluation of policy measures (Blau and Gilleskie (2006) and Van der Klaauw and Wolpin (2008)).

Reverse causality makes it challenging to identify the effect of, say, the husband's retirement choice on the labor market status of the wife using observational data, since both spouses' labor supply choices may be linked directly and indirectly through both observables and correlated unobservables, or shocks. Using Dutch administrative micro data at the population level and relying on identification through a quasi-natural experiment, we find robust evidence for important spillovers of the husband's retirement decision on his wife's retirement status emanating from his changed financial incentives to retire early.

The policy change that we exploit became effective in 2005 for certain birth cohorts of civil servants employed for more than ten years by the Dutch central government. These individuals were offered the opportunity to retire during the year 2005 , by a temporary reduction of the ER eligibility age. For our empirical work, we focus on stable dual-earner couples in which the husband did and the wife did not work in the public sector, such as to rule out coincidental treatment of wives through the same reform. Both husbands and wives in our sample had a strong labor force attachment.

The wife's probability to retire is the dependent variable in our model. We employ the mentioned policy change as an instrument for husband's retirement status, and control for both observable characteristics and unobservables. We use an individual fixed effects specification for the latter. Fixed 
effects also control non-parametrically for cohort effects that may arguably be important. In addition, we control for year fixed effects and nonlinear age effects. Since couples were stable dyads in our sample, we identify an effect over and above fixed differences in ages. According to our central estimates, retirement of male civil servants led to a jump in the probability of their wives to retire within one year by 24.6 percentage points. This is a large effect, given that those wives pursued their own careers and had a strong labor market attachment.

There are two related literatures that our work speaks to. One focuses on joint retirement using structural models. These models assume that husbands and wives make separate retirement decisions and have their own preferences. Appropriate modelling of the relevant financial incentives and suitable parameterization of individual preferences are some of the main challenges in this literature. Papers such as Blau and Gilleskie (2006) and Van der Klaauw and Wolpin (2008) carefully model the incentives provided by social security rules, and specify stochastic processes for wages, health and survival. The main effect of husbands' on wives' retirement choices runs through the household budget constraint in those papers. The household budget constraint is not the only channel inducing dependence, however. Spouses enjoy spending time together, i.e. spousal preferences directly depend on one another. Gustman and Steinmeier (2000), studying retirement choices assuming absence of uncertainty, find that spouses coordinate retirement decisions and that coordination of retirement decisions is motivated by leisure complementarities rather than financial incentives provided by the household budget constraint. Casanova Rivas (2010) does take into account uncertainty regarding future income, health and survival. In line with Gustman and Steinmeier (2000), she finds evidence for leisure complementarities.

We directly contribute to a second strand of a very recent empirical literature that estimates the effect of retirement of one partner on retirement status of the spouse. ${ }^{1}$ The identification methods used in this literature do not rely on distributional assumptions, but rather on exogenous sources of variation in the retirement rates. Hospido and Zamarro (2014) and Banks, Blundell and Casanova Rivas (2010) are the survey data studies most comparable to ours. They both find that spousal decisions can be influenced by retirement shifts of their partners. They use variation in eligibility ages for early retirement benefits between countries as source of variation in the probability to retire. A remaining objection with approaches that rely on fixed age rules is that retirement induced by reaching the eligibility age for early retirement benefits could be anticipated long in advance. Workers may then have reduced the number

\footnotetext{
${ }^{1}$ There is a literature that studies the coordination of labor force participation of spouses. Lundberg (1988) and Goux, Maurin and Petrongolo (2014) are two of the main papers in that literature.
} 
of hours worked or may have started to live healthier, so that they would have been better able to continue working, for instance. Such anticipation effects could bias the estimated treatment effect toward zero. Our research design relying on a shock to eligibility conditions avoids this in principle.

Our first contribution is to use strong instruments that provide exogenous (unanticipated) variation in retirement rates of husbands, as explained above. Second, we use administrative data that include end dates of jobs and that allow us to observe the precise within-couple sequencing of retirement. This is critical in order to rule out that our estimates are influenced by behavior of wives that actually retired earlier than their husbands. The latter effect cannot necessarily be ruled out in studies that are based on biennial survey data, posing a potential threat to identification. Third, as we have access to data covering the entire population, we can focus on a sample of particular interest, namely individuals from a very narrow age range and where we can (to some degree) control for historical labor market attachment.

The rest of the paper is set up as follows. Section 2 reviews the relevant related literature and Section 3 describes the institutional environment, including the policy change that we exploit. Section 4 explains and describes the data. Section 5 delineates the identification strategy we use for estimating the causal effect of husband's retirement on wife's retirement status. Section 6 discusses the results and Section 7 concludes.

\section{Literature review}

Hospido and Zamarro (2014) employ a fuzzy Regression Discontinuity design using the eligibility age for early retirement benefits as discontinuity in the probability to retire. They use data from the Survey on Health, Ageing and Retirement in Europe (SHARE) covering eleven European countries and find that induced retirement of husbands increased the probability that their wives retired in the same two-year interval between survey waves by 16-18 percentage points. Banks, Blundell and Casanova Rivas (2010) employ a difference-in-difference approach, exploiting the difference in eligibility ages for early retirement benefits between the UK and the US as a source of variation in retirement status. They use data from the 2002 and 2004 waves of the Health and Retirement Study (HRS) for the US and from the English Longitudinal Study of Ageing (ELSA) for the UK. The eligibility age for early retirement benefits was 62 in the US and 60 in the UK. Conditioning on couples in which the wife turned 60 between two survey waves, American husbands form the control group, and British men constitute the treatment 
group. The authors find that men in the UK were 14-20 percentage points more likely to retire when their wives reached the early retirement age than comparable men in the US. They find a similar effect after employing instrumental variable estimation, using the early retirement age as a source of exogenous variation for retirement status of the wives.

Stancanelli (2012) employs a fuzzy Regression Discontinuity design, using age 60, the youngest early retirement age in France, as the discontinuity in the probability to retire. She uses data from the French Labour Force Surveys (LFS). She finds a positive effect of retirement on the partner's hours worked, both for male and female partners. Zweimueller, Winter-Ebmer and Falkinger (1996) estimate a bivariate probit model, where the dependent variables are the retirement statuses of the husband and the wife. The retirement status of each of the partners depends on the social security variables of both spouses. Using data from the Austrian Microzensus, the authors find that husbands responded to a change in the minimum retirement age of their wives whereas wives did not respond to a change in minimum retirement age of their husbands. Baker (2002) estimates the effect of a decrease in the eligibility age for age-related income security benefits for workers who were younger than their spouses on labor force participation of spouses in Canada. He uses data from the Canadian Survey of Consumer Finances. The author finds that eligibility for the age-related benefits for wives was associated with a six to seven percentage point decrease in labor force participation of husbands. He does not find an association between eligibility for the age-related benefits of husbands and labor force participation of wives.

\section{Institutional background and policy change}

We study the case of the Netherlands. We exploit temporary age-specific retirement incentives for civil servants as a source of exogenous variation in retirement rates. At the time of the policy change in 2005, the normal (or, statutory) retirement age was 65 , for both men and women. Actual retirement ages have been substantially lower, due to the use of early retirement arrangements being widespread in almost all sectors. ${ }^{2}$ The average age at which workers aged 55 and older retired in 2005 was 61 for both men and women (Statistics Netherlands, 2014).

The Netherlands has a pension system that rests on three pillars (Bovenberg and Meijdam, 2001). The first pillar consists of universal flat-rate public old-age pensions, financed on a pay-as-you-go basis. The

\footnotetext{
${ }^{2}$ A detailed description of the Dutch pension system and early retirement arrangements specifically available to civil servants can be found in the Appendix.
} 
second pillar concerns occupational pensions. These are funded. Coverage rates are in the order of magnitude of 90 percent for employees. The third pillar includes private provisions. During the period 2000-2005, most occupational pension funds offered early retirement arrangements. So did the public sector pension fund. Its early retirement arrangements typically made it possible to retire as of the ages 61 or 62 . We exploit a temporary decrease in the ER eligibility age for civil servants as a source of exogenous variation in husbands' retirement probability to estimate the impact of early retirement of husbands on their wives' probability to retire within one year. ${ }^{3}$

The Dutch central government announced a temporary decrease in ER eligibility age for its workers in April 2004. This decrease is referred to as 'the early retirement window' in the remainder of this paper. As a part of a reorganization of the central government, certain civil servants employed at central government organizations were allowed to be offered possibilities for early retirement in the year 2005 at lower than common ages. Central government organizations only had permission to offer early retirement if this would save existing jobs of younger civil servants at the level of the organization. ${ }^{4}$ In practice, each of the central government organizations offered early retirement collectively to its eligible workers, so to either all or none of them (Dutch Government, 2004). This aspect prevented that the early retirement window was targeted at workers whose wives had a relatively low or high probability to retire in the year to come. ${ }^{5}$ The gross retirement benefits offered by the early retirement window were equally generous as those associated with regular ER programs and could have been up to 70 percent of workers' average gross wages. ${ }^{6}$

Civil servants could only enter the early retirement window if they met several eligibility criteria (Dutch Government, 2004, 2005). First, civil servants had to be 55 or older on the day of early retirement. Second, they were required to have had a continuous employment tenure as a civil servant of at least ten years prior to early retirement. Third, they needed to have contributed to the public sector pension fund continuously during the ten years prior to early retirement. The second and third requirement are important for our identification strategy, because they prevented self-selection into the public sector of

\footnotetext{
${ }^{3}$ We consider a 12 month period, not a calendar year.

${ }^{4}$ Saving existing jobs refers to preventing forced layoff due to reorganization.

${ }^{5}$ If early retirement would have been offered to workers individually, employers may have offered it only to illhealth workers or to workers with a low productivity due to having a poor health. This might bias the estimate of the treatment effect of interest upwards.

${ }^{6}$ Net replacement rates could have been higher than 70 percent of workers' mid-career salaries. Replacement rates depended among others on the birth dates of individuals. The early retirement window was not actuarially fair, but rather quite advantageous for workers.
} 
workers who planned to benefit from the extra ER incentive. Central government employers had to decide before 1 January 2005 whether to open the early retirement window and entering civil servants had to retire on or before 1 December 2005. The early retirement window offered early retirement benefits to workers until they reached the age of 65 and with a duration of no longer than eight years. This implies that civil servants aged 57 or older at the day of early retirement were entitled to retirement benefits for the full period until their normal retirement at age 65 . Civil servants who were born before 1 January 1948 could let the employer pay for 50 percent of the pension accrual for at most four years. The early retirement window for civil servants thus provided strong incentives to retire for those 58 or older, slightly weaker incentives for those aged $57^{7}$ and much weaker incentives at ages 55 or 56 .

\section{Data}

We use administrative data collected and prepared for research purposes by Statistics Netherlands. The main data we use cover the period 2000-2005 and include variables on job and personal characteristics. ${ }^{8}$ The job characteristics data provide information on all jobs any individual registered in the Netherlands has been employed in. The job information includes job spells (precise start and end dates per job), the industry code and the annual wage. The personal characteristics data contain information on demographic characteristics for the whole Dutch population. The demographic characteristics include nationality, marital status, birth year and birth month. The personal characteristics data also include a partner identifier that allows us to link partners to each other.

We select observations on opposite-sex couples for which both members were in the age category 5360 in the year of observation. ${ }^{9}$ We select observations on couples who had been married for at least five years on December $31^{\text {st }}$ of the year of observation. We do so, because couples who had a stable marriage may have been more likely to plan the future together and may therefore have been more likely to coordinate retirement than couples who had been married for a relatively short time. We exclude observations on couples in which at least one of the spouses did not possess the Dutch

\footnotetext{
${ }^{7}$ The early retirement window thus was "an offer they could not refuse" for workers aged 57 and older.

8 The original file names are Doodsoorzaken (2000-2005), Landelijke Medische Registratie (LMR, 1998-2004), SSB Banen (1999-2008), SSB Personen (2000-2005) and PARTNERBUS (2010). Unfortunately, for the years we are interested in, there are no data available on e.g. financial wealth.

${ }^{9}$ Being married includes having a registered partnership. Registered partnership refers to partnerships enjoying legal status similar to marriage. Being married excludes cohabitation without being married or without having a registered partnership.
} 
citizenship during the year of observation. The motivation for this exclusion is that workers who did not have the Dutch citizenship may have had an increased probability to have resided and worked outside the Netherlands for a longer period during their working lives. Workers did not accumulate public oldage pension rights when residing abroad and typically did not accumulate early retirement pension rights when working abroad. This may have negatively affected accumulated public old-age pension rights, and accumulated early retirement pension rights for the affected wives in particular. As early retirement opportunities of the affected wives may have been limited, these wives may not have retired early, irrespective of the retirement decisions made by their husbands.

We exclude observations for which the husband had not been continuously employed as a civil servant for the ten years prior to January $1^{\text {st }}$ of the year of observation. We do also exclude observations for which the wife had not been continuously employed outside the public sector for the ten years prior to January $1^{\text {st }}$ of the year of observation. We make these selections for the following reasons. First, because one of the eligibility criteria for making use of the early retirement window was that husbands had been continuously employed as civil servants for the ten years prior to commencing early retirement. Our selection ensures that husbands in the dataset could have been eligible for entering the early retirement window for civil servants, and wives could not have been. Second, because workers with a continuous employment tenure of at least ten years had a strong labor force attachment. Wives and husbands who had a weak labor force attachment may not have engaged in career planning and may so not have planned retirement or coordinated retirement with their spouses. As an additional measure to ensure that the workers we study had a strong labor force attachment, we exclude observations on workers who earned less than 15,000 euros in the year prior to the year of observation.

Observations on couples that included at least one spouse who died in the year of observation or had been hospitalized somewhere between 1999 and the final year of observation are also excluded from the sample. By making this selection we aim to limit the potential endogeneity of retirement status to health. We use retirement of the first retiring member of the couple as an absorbing state. This implies that we do not use observations for years after a member of the couple had retired.

In Section 6.3.2, we perform robustness checks on the various aspects of our data selection. In general, we find that our result is robust to changing the data selection criteria. We use about 7,300 observations for our analysis. Our analysis focuses on the effect of retirement of the husband on retirement status of the wife. We do not estimate the reverse relationship because of a lack of observations. There were too few wives induced to retire by the introduction of the early retirement arrangement we use. This may 
have to do with the fact that labor market attachment of women in the Netherlands was not uniformly strong.

Table 1 shows descriptive statistics for couples that include a wife who was employed outside the public sector, i.e. a wife who was employed, but not as a civil servant. Wife's and husband's age are measured on December $31^{\text {st }}$ of the respective year. Wife's and husband's wage income (at $t-1$ ) indicate the total wage income the wife and her husband earned in the year prior to the year of observation. The wage income variables are measured in thousands of deflated euros.

The control group in our instrumental variable model includes wives whose husbands were employed as civil servants in 2005 and were 53 or 54 years old in 2005, i.e. wives with husbands who were ineligible to withdraw from the labor force through the special early retirement window. The treatment group includes wives whose husbands were employed as civil servants in 2005 and were in the age category $55-60$ in 2005, i.e. women partnered with those civil servants who could have been offered early retirement. Table 1 shows that wives in the control group had a similar wage income in the year prior to the year of observation as wives in the treatment group. Wage income of husbands and wives (at $t-1$ ) was also similar for the treatment group as for similarly selected couples in the years before the early retirement window was opened. For the external validity of our study, it is important to notice that couples that included a husband who was employed as a civil servant were in general comparable, in terms of observables, to couples that included a husband who was employed outside the public sector. ${ }^{10}$

The early retirement window was opened for civil servants employed by certain central government organizations. We do not directly observe early retirement window offers at the level of individual workers. This implies that we cannot observe whether a civil servant who did not retire rejected the early retirement offer or simply was not offered the early retirement window. Hence the "treatment" group as defined in our data is somewhat larger than the "true" treatment group. ${ }^{11}$ Important to notice is that the early retirement window was offered to workers in departments or organizations within the central government collectively rather than to individual workers. This makes it unlikely that there was individual selection in offering the early retirement window.

\footnotetext{
${ }^{10}$ We impose comparable selection criteria (esp. tenure in industry) on husbands employed outside the public sector as for the treatment group.

${ }^{11}$ We do not know how much smaller the "true" treatment group is than the observed treatment group.
} 


\section{Methodology}

We employ an instrumental variable approach to estimate the impact of early retirement of the husband on retirement status of the wife. We instrument the retirement choice of the husband using dummy variables for the ages at which husbands were eligible for entering the early retirement window, interacted with a dummy variable for the year 2005 , i.e. the year of the policy change. ${ }^{12}$ We estimate our model using only observations on wives employed outside the public sector whose husbands were employed as civil servants. We use wives whose husbands were aged 53 or 54 in 2005 as the control group and wives whose husbands were in the age category 55-60 in 2005 as the treatment group. ${ }^{13}$ We assume that, conditional on the covariates and treatment status, wives whose husbands were aged 53 or 54 in 2005 were similar in terms of the probability to retire to those who had husbands in the age category 55-60 in 2005. We think this is reasonable, as factors influencing the probability to retire across the lifecycle such as age, age of the husband, wage income and health are controlled for. The model controls for time-invariant heterogeneity as well. The treatment effect we estimate is a Local Average Treatment Effect (LATE), i.e. the effect of husband's early retirement on the wife's probability to retire within one year for those couples for whom the husband was induced to retire early by variation in the eligibility conditions.

\subsection{Instrument validity}

The validity of our instruments hinges on the satisfaction of two conditions. First, the instruments have an impact on the probability that husbands retired. Second, the instruments do not correlate with unobserved factors having an impact on the probability that wives retired.

Figure 1 shows retirement rates for husbands who were employed as civil servants. We see some very pronounced patterns. Husbands in the age category 55-60 had higher retirement rates in 2005 than in earlier years. The difference in retirement rates between 2005 and earlier years was especially large for husbands in the age category 57-60. Husbands aged 53 or 54 had similar retirement rates in 2005 as in earlier years. This is all in line with the age-specific incentives as provided by the temporary decrease in

\footnotetext{
${ }^{12}$ Bloemen, Hochguertel and Zweerink (2013) employ a similar identification strategy to estimate the effect of retirement on the probability to die within five years.

${ }^{13}$ We do not use wives with husbands employed in a particular industry other than the public sector and in the age category 55-60 as the control group, because there was no industry whose workers were similar in terms of observables and faced similar pension incentives as civil servants.
} 
eligibility age in early retirement benefits, as discussed in Section 3. This supports our hypothesis that our instruments are relevant.

To our knowledge, there were in 2005 no similar early retirement windows in sectors other than the public sector. We thus do not expect the opening of the early retirement window to have had a direct impact on the probability that the wives in our sample retired. We are also not aware of any event other than the opening of the early retirement window that may have affected the probability to retire for husbands employed as civil servants and in the age category 55-60 in 2005. We expect that our instruments are not correlated with unobserved factors that influenced the wives' probability to retire. Wives' unobserved health, number of hours worked or stress levels associated with work are among the unobserved factors that may have influenced wives' probability to retire. These factors may be affected if retirement of the husband could have been anticipated. Correlation due to anticipation of the opening of the early retirement window, however, is not expected to be an issue. This is because the opening of the early retirement window was only announced by the government in April 2004 and central government employers only decided after that time whether and to whom they would actually open the early retirement window. Selection into public sector jobs by husbands or wives after the announcement of the policy change is not an issue either. The reason for this is that eligibility for entering the early retirement window required individuals to have been employed as civil servants continuously for the ten years prior to early retirement and to have contributed to the public sector pension fund during the ten years prior to early retirement.

Another possible threat to the exogeneity of our instruments is that factors other than the opening of the early retirement window may have boosted retirement rates for civil servants in 2005. Changes in disability insurance may, for instance, have affected retirement rates of civil servants. ${ }^{14}$ Figure 2 shows that retirement rates for husbands employed outside the public sector and in the age category 55-60 were not higher in 2005 than in other years. This indicates that there were no factors affecting retirement rates of husbands in general in 2005. It could also be that retirement rates for wives with husbands in the age category 55-60 were higher in 2005 than in earlier years, irrespective of the sector the husbands were employed in. The introduction of a policy that provided wives with an incentive to retire in 2005 if their husbands were born in certain years, for instance, may have caused such a deviation. Figure 3 shows that retirement rates for wives employed outside the public sector with

\footnotetext{
${ }^{14}$ Disability insurance (DI) and its relation to early retirement are discussed in the Appendix. DI is a universal social insurance scheme and not sector-specific.
} 
husbands employed outside the public sector and in the age category 55-60 were not higher in 2005 than in earlier years.

Figure 4 shows that retirement rates for wives with husbands aged 60 in 2005 were much higher than for wives with younger husbands in 2005 and for wives with husbands aged 60 in previous years. This may suggest that if we find an effect of retirement of the husband on retirement status of the wife, this effect may be driven by wives whose husbands were aged 60 in 2005.

\subsection{Model specification}

We employ a two-stage-least-squares fixed effects (FE) instrumental variable model to estimate the LATE. In the first stage, retirement status of the husband is estimated and in the second stage, the impact of predicted retirement of the husband on the wife's probability to retire is estimated. As we use a fixed effects model, our model has the advantage that it controls for effects of time-invariant individual characteristics and allows individual fixed effects and observed characteristics to be correlated with each other. We control for year effects and for differences in wife's and husband's probability to retire across age. We specify the first stage of our model as follows:

$$
\begin{aligned}
& H_{i t}=e_{0}+\sum_{j=2000}^{j=2004} b_{j} D_{j t}+\sum_{k=2}^{k=3} c_{k} A_{k i t}+\sum_{k=2}^{k=3} c_{k p} A_{k i t p}+\sum_{l=55}^{l=60} d_{05 l p} D_{05, t} E_{l i t}+g_{i t-1}^{\prime} m \\
& +e_{i}+v_{i t}
\end{aligned}
$$

where $H_{i t}$ is a dummy that is 1 if the husband of couple $i$ retired in year t. ${ }^{15} H_{i t}$ is 0 otherwise. $D_{j t}$ is a year dummy that is 1 in year $j$ and 0 otherwise. $A_{k i t}\left(A_{k i t p}\right)$ denotes the difference between the age of the wife (husband) in couple $i$ in year $t$ and 53 , taken to the $k$ th power. ${ }^{16} E_{l i t}$ is an age dummy that is 1 if the husband in couple $i$ reached age $l$ in year $t$ and 0 otherwise. $g_{i t-1}$ includes wage income of the wife (at $t-1$ ) and wage income of the husband (at $t-1) . v_{i t}$ is an error term. $e_{i}$ is an individual fixed effect that is allowed to be arbitrarily correlated with all covariates.

\footnotetext{
${ }^{15} H_{i t}$ is a dummy that is 1 if the husband of couple $i$ retired in year $t$ only if the husband retired before the wife. This is because we use retirement of the first retiring member of the couple as an absorbing state.

${ }^{16}$ We do not include $A_{1 i t}$ and/or $A_{1 i t p}$ in our models. Including $A_{1 i t}$ and/or $A_{1 i t p}$ is not possible due to multicollinearity caused by the presence of the year dummies.
} 
The second stage is specified as follows:

(2) $\quad W_{i t}=\alpha_{0}+\sum_{j=2000}^{j=2004} \gamma_{j} D_{j t}+\sum_{k=2}^{k=3} \delta_{k} A_{k i t}+\sum_{k=2}^{k=3} \delta_{k p} A_{k i t p}+g_{i t-1}^{\prime} \varphi+\omega \widehat{H}_{i t}+\alpha_{i}+u_{i t}$

where $W_{i t}$ is a dummy that is 1 if the wife in couple $i$ retired in year $t$ and 0 otherwise. All other variables are as specified above for the first stage. $\omega$, the coefficient on the predicted retirement indicator of the husband, indicates the LATE. Fixed effects $\alpha_{i}$ are allowed to be correlated with all covariates. $\alpha_{i}$ and $e_{i}$ are also allowed to be correlated with one another. $u_{i t}$ and $v_{i t}$ are allowed to be correlated with each other as well.

\section{Results}

\subsection{The uninstrumented case}

It is instructive to first consider a regression of wife's retirement status on the husband's retirement status without correcting for potential endogeneity. Table 2 shows that the coefficient estimate on retirement status of the husband is minus 2.4 percentage points and significant at the ten percent significance level, conditional on fixed effects and observables. This would suggest a negative association between retirement dates within the couple.

\subsection{Instrumental variable estimates}

Table 3 shows the instrumental variable fixed effects estimate. ${ }^{17}$ The coefficient estimate on retirement of the husband indicates that retirement of husbands induced by the opening of the early retirement window actually increased their wives' probability to retire within one year by 24.6 percentage points. This effect is significant at the ten percent level. Interestingly, the coefficient estimate on retirement of the husband has the opposite sign in the instrumented case compared to the uninstrumented case. This suggests that retirement status of the husband is indeed endogenous to the retirement status of the wife. The coefficient estimate on instrumented retirement of the husband, which indicates the LATE, is slightly larger than the effects found by Hospido and Zamarro (2014) and Banks, Blundell and Casanova Rivas (2010). They, respectively, find a positive effect of 16-18 percentage points and 14-20 percentage points of retirement of the husband on wives' probability to retire within the same two-year time

\footnotetext{
${ }^{17}$ Table 6 shows the first and second stage estimates.
} 
interval. The F-statistic in the first stage shows that our instruments are jointly relevant at the one percent significance level.

\subsection{Robustness checks}

\subsubsection{Robustness checks on the model specification}

\section{Functional form specification: Age dummies and nonlinear age and year terms}

Our statements concerning the probability to retire are to be understood conditional on wife's and husband's age. Wife's age is an important determinant of retirement status of the wife, as is husband's age an important determinant of retirement status of the husband. This may make our result sensitive to the specification of the age function used in our model. We control for polynomial second and third order wife's and husband's age effects in our instrumental variable model. As a robustness check, we estimate the instrumental variable model once controlling for second order wife's and husband's age effects only and once controlling for a fourth-degree polynomial in wife's and husband's age. Table 4 (variations a-d) shows that the LATE estimates for the alternative models are similar to the LATE estimate for the baseline model. This indicates that our instrumental variable result is robust to controlling for wife's and husband's age effects of one order lower or one order higher (variations a and b). Our instrumental variable result is robust to controlling for wife's and husband's age fixed effects rather than nonlinear age effects (variation c) and non-linear year effects rather than year fixed effects (variation d) as well. ${ }^{18}$

\section{Individual effects: random effects and no individual effects}

We also estimate the instrumental variable model with individual random effects (RE). Variation in estimates may point to individual effects being correlated with covariates. We estimate the RE instrumental variable model using the baseline specification as in (1) and (2). We add husbands' and wives' birth year dummies to the existing set of independent variables to control for birth year fixed effects for both spouses. Table 4, variation e, shows that the LATE estimated using the RE model is significant at the one percent level and that it is almost identical to the LATE estimated using the FE

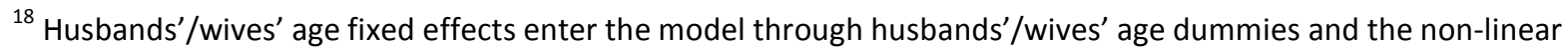
year effects are controlled for in the model by including the terms $(\text { year }-2000)^{2}$ and $(\text { year }-2000)^{3}$.
} 
model. ${ }^{19}$ This suggests that individual effects and covariates are only weakly correlated with each other. Lastly, we estimate the instrumental variable model without individual effects but with the husbands' and wives' birth year dummies to verify how sensitive our result is to not controlling for unobserved heterogeneity. The LATE estimated using the model without individual effects is almost equal to the baseline LATE (variation f).

\subsubsection{Robustness checks on data selection}

\section{Selection on age}

Our dataset includes observations on workers in the age category 53-60. The control group consists of wives with husbands who were aged either 53 or 54 in 2005. Because we use a fixed effects model, the control group effectively consists of wives whose husbands were aged 54 in 2005 only. We now include observations on wives and husbands aged 52 for all years and extend our control group to wives whose husbands were in the age category 52-54 in 2005 to verify whether our result is not driven by particular characteristics of either male civil servants aged 54 in 2005, or their wives' characteristics. Table 5 , variation a, shows that our result is robust to adding observations on workers aged 52 for all years to our dataset and adding wives with husbands aged 52 in 2005 to the control group.

\section{Selection on Dutch citizenship}

Workers without Dutch citizenship and their spouses may have resided and worked a shorter part of their working lives in the Netherlands than couples consisting only of workers with Dutch citizenship. Dutch pension rules may have made working and residing abroad have a negative effect on accumulated (early retirement) pension rights, which may have provided affected wives in particular with a disincentive to retire early. We selected observations on workers with Dutch citizenship for our analysis, because wives provided with a disincentive to retire early may have been unlikely to be induced to retire by retirement of their husbands. Table 5 , variation $b$, shows that the LATE estimated for the dataset including observations on workers without Dutch citizenship is similar to the baseline LATE, however.

\section{Selection on wage income}

We selected observations on workers who had a wage income during the year prior to the year of observation of at least 15,000 euros. Not having recourse to information on hours worked, we did so to

\footnotetext{
${ }^{19}$ The coefficient estimates on retirement of the husband in the random effects and fixed effects model do not differ from each other at the five percent significance level.
} 
make sure that husbands and wives in our sample had a strong labor force attachment. Workers with a weak labor force attachment may not have done career planning and may not have planned or coordinated retirement with their spouses. We may therefore not expect there to be an effect for this group of workers. Table 5 shows that the LATE estimate is slightly lower than the baseline LATE estimate if observations on workers with a wage income (at $t-1$ ) of at least 10,000 euros are included (variation c) and higher if observations on workers with a wage income (at $t-1$ ) lower than 20,000 euros are excluded (variation d). This suggests that workers with a stronger labor force attachment were indeed more likely to coordinate retirement with their spouses.

\section{Selection on hospitalization}

III-health workers may have had a higher probability to retire early than healthy workers. Workers with ill-health partners may also have had a higher probability to retire early than workers with healthy partners (possibly to provide spousal care). We have tried to limit the potential bias due to the endogeneity of retirement status of the husband and wife to both spouses' ill-health. We did so by dropping observations on couples including at least one spouse who died in the year of observation or had been hospitalized between 1999 and the final year of observation. Table 5, variation e, shows that the LATE is insignificant if it is estimated on a sample that also includes couples in which at least one member was hospitalized between 1999 and the final year of observation. The sample size increases with $39 \%$ compared to our baseline sample. The intuition for this finding is that adverse health shocks trigger retirement irrespective of any financial incentives provided. This drives the LATE towards zero.

\section{Selection on marriage duration}

Couples who had a stable marriage may have been more likely to plan the future together and may therefore have been more likely to coordinate retirement than couples who had been married for a relatively short time. We have estimated the LATE for observations on husbands and wives who had been married for at least five years on December $31^{\text {st }}$ of the year of observation. Table 5 , variation $\mathrm{f}$, shows that the LATE is insignificant if it is estimated for observations on couples who had been married for at least one year on December $31^{\text {st }}$ of the year of observation. This suggests that couples with shorter or less stable marriages did not coordinate retirement. The LATE estimated for observations on couples who had been married for at least ten years on December $31^{\text {st }}$ of the year of observation (variation $\mathrm{g}$ ) is, however, similar to the baseline LATE. 


\section{Selection on husbands' occupation}

We selected observations on wives with husbands who were employed as civil servants. Workers employed as civil servants may have had different retirement patterns than workers employed outside the public sector. This may have affected our result. As a robustness check, we estimate the LATE using data on wives with husbands who were either employed as civil servants or employed outside the public sector. The husbands employed outside the public sector are selected in a similar way as the husbands employed as civil servants. The model we estimate is the model specified in (1) and (2), except that the instruments, i.e. the interactions between the dummy for the year 2005 and the dummies for the husband's ages 55-60, are multiplied by a dummy for the husband being employed as a civil servant. Table 5, variation $\mathrm{h}$, shows that our result is robust to correcting for civil servant-specific retirement patterns.

\section{Conclusions}

We investigate interactions between individuals' retirements by using a quasi-natural experiment where policy variation induces the husband to retire early. We then estimate the chance that the wife responds to the retirement choice of the husband. In order for our exercise to be meaningful, we focus on couples where only the male, but not the female, was subject to specific early retirement incentives, where both spouses can be characterized as having a strong labor market attachment, and where the couple forms a stable dyad, so as to make it plausible that joint planning of retirement is likely.

We benefited from having administrative data from the Netherlands and having a strong and exogenous source of variation in retirement status of the husband at our disposal. We have found that induced retirement of husbands increases the probability that the wife retires within one year by 24.6 percentage points. This result, which is robust, indicates that the temporary decrease of the eligibility age for early retirement benefits for male civil servants has strong spillovers to their spouse. The effect is driven by husbands aged 60 who had a wife aged 59 or 60 . This is interesting, because in sectors other than the public sector, age 60 was a common eligibility age for early retirement benefits. Interactions between the early retirement window under review and regular early retirement arrangements in other sectors may thus play a role in the couples' decision to retire.

The findings suggest that policy makers ought to take into account that changes in pension and retirement system parameters may not only affect the individuals that reforms aim at, but also their 
associated spouses. To the extent that the underlying mechanisms symmetrically apply to increases in retirement age, a double dividend of increasing retirement ages is conceivable. This is relevant, also when considering the spillovers of the introduction or abolition of age-specific retirement incentives to retirement status of spouses in contexts and countries other than the ones currently studied. 


\section{References}

Baker, M. (2002), "The Retirement Behavior of Married Couples: Evidence from the Spouse's Allowance", Journal of Human Resources 37: 1-34

Banks, J., R. Blundell and M. Casanova Rivas (2010), "The dynamics of retirement behavior in couples: Reduced-form evidence from England and the US", preliminary version

Berkovec, J. and S. Stern (1991), “Job Exit Behavior of Older Men", Econometrica 59: 189-210

Blau, D.M. and D.B. Gilleskie (2006), "Health insurance and retirement of married couples", Journal of Applied Econometrics 21: 935-953

Bloemen, H., S. Hochguertel and J. Zweerink (2013), "The Causal Effect of Retirement on Mortality Evidence from Targeted Incentives to retire early", Tinbergen Institute Discussion Paper No. 2013-119/V

Bloemen, H., S. Hochguertel and J. Zweerink (2014), "Gradual Retirement in the Netherlands: An Analysis Using Administrative Data", manuscript

Blundell, R., A. Bozio, and G. Laroque (2013), "Extensive and intensive margins of labour supply: Work and working hours in the US, the UK and France", Fiscal Studies 34: 1-29

Bovenberg, A.L. and L. Meijdam (2001), "The Dutch pension system", in A.H. Börsch-Supan and M. Miegel (eds.), "Pension reform in six countries. What can we learn from each other?", Berlin: Springer, pp. 39-67.

Casanova Rivas, M. (2010), "Happy Together: A Structural Model of Couples' Joint Retirement Choices", work in progress

Dutch Government (2004), "Sociaal flankerend beleid sector Rijk", Staatscourant 115, 21 June 2004

Dutch Government (2005), "Besluit van 31 december 2004, houdende vaststelling van een aantal tijdelijke rechtspositionele voorzieningen van sociaal flankerend beleid voor de sector Rijk die gelden van 1 maart 2004 tot 1 januari 2008", Staatsblad 29, 25 January 2005

Goux, D., E. Maurin and B. Petrongolo (2014), "Worktime Regulations and Spousal Labour Supply", American Economic Review 104: 252-276

Gustman, A.L. and T.L. Steinmeier (1986), "A Structural Retirement Model", Econometrica 54: 555-584

Gustman, A.L. and T.L. Steinmeier (2000), "Retirement in Dual-Career Families: A Structural Model", Journal of Labor Economics 18: 503-545 
Hospido, L. and G. Zamarro (2014), "Retirement Patterns of Couples in Europe", IZA Journal of European Labor Studies, 3:12

Lumsdaine, R., J. Stock and D. Wise (1992), "Three Models of Retirement: Computational Complexity vs. Predictive Validity", in D.A. Wise (ed.), "Topics in the Economics of Aging", Chicago: University of Chicago Press, pp. 21-60.

Lundberg, S. (1988), "Labor Supply of Husbands and Wives: A Simultaneous Equations Approach", The Review of Economics and Statistics 70: 224-235

Rust, J. and C. Phelan (1997), "How Social Security and Medicare Affect Retirement Behavior in a World of Incomplete Markets", Econometrica 65: 781-831

Schirle, T. (2008), "Why have the labor force participation rates of older men increased since the mid1990s?", Journal of Labor Economics 26: 549-594

Stancanelli, E. (2012), "Spouses' Retirement and Hours of Work Outcomes: Evidence from Twofold Regression Discontinuity", CES Working paper No. 2012.74

Statistics Netherlands (2006), "Groei aandeel arbeidsongeschikte vrouwen voorbij", Webmagazine, October 9th, 2006

Statistics Netherlands (2014), data retrieved on April $16^{\text {th }}, 2014$ from http://statline.cbs.nl/StatWeb/publication/?DM=SLNL\&PA=80396NED\&D1=1,9\&D2=1-2\&D3=0\&D4=0$2 \& D 5=1-2 \& D 6=0-2,8,15 \& D 7=0 \& D 8=5 \& H D R=G 1, G 2, G 3, G 6, T, G 7 \& S T B=G 4, G 5 \& V W=T$

Van der Klaauw, W. and K.I. Wolpin (2008), "Social security and the retirement and savings behavior of low-income households", Journal of Econometrics 145: 21-42

Zweimueller, J., R. Winter-Ebmer and J. Falkinger (1996), "Retirement of Spouses and Social Security Reform", European Economic Review 40: 449-472 


\section{Appendix $^{20}$}

\section{The Dutch pension system}

The Dutch pension system rests on three pillars (Bovenberg and Meijdam, 2001). The first pillar is the public old-age pension. The public old-age pension is financed on a pay-as-you-go basis.

Contributions stem from workers and employers. All residents registered in the Netherlands accrue public old-age pension rights. Public old-age pension benefits are flat. For couples they equal the minimum wage. ${ }^{21}$ Singles receive 70 percent of the minimum wage. For every year between the ages 15 and 65 that individuals did not reside in the Netherlands, public old-age benefits are cut by two percentage points.

The second pillar consists of occupational pensions, most frequently of the defined benefit type. Occupational pensions are funded pensions and are typically managed at the industry level and sometimes at the firm level (for large employers). About 90 percent of all workers participate in an occupational pension plan with contributions from both workers and employers. Workers who participate in a pension plan pay contributions over the difference between their wage and a nominal threshold called the "franchise". The "franchise" roughly equals the public old-age benefit level for married individuals. The aggregate of first and second pillar pension benefits provided pension benefits as of age 65 with replacement rates of up to 70 percent of workers' gross mid-career salaries. Owing to the large number of occupational pension plans, there is considerable heterogeneity in pension conditions. ${ }^{22}$ The age as of which workers can retire, the eligibility criteria, whether pension benefits are based on end-of-career or mid-career salaries, and the generosity of pension benefits vary substantially across pension funds. ${ }^{23} 24$

Occupational pension funds typically offered early retirement pensions to their participants. Early retirement pensions allowed full retirement as of a specific age. The early retirement eligibility age generally varied from 60 to 62 . Eligibility criteria for early retirement benefits may include a minimum

\footnotetext{
${ }^{20}$ Parts of the Appendix are obtained from Bloemen, Hochguertel and Zweerink $(2013,2014)$.

${ }^{21}$ Both spouses receive 50 percent of the minimum wage.

22 There are approximately 80 pension funds. About 55 of these are profession-wide or sectoral pension funds, while 25 are firm-specific.

${ }^{23}$ Across the years of observation, a large number of pension funds switched from a regime that based pension benefits on end-of-career salary to a mid-career salary regime. The public sector pension fund was one of the earliest switchers with its conversion on January 1, 2004.

${ }^{24}$ Replacement rates of the DB pension benefits depended on, amongst others, the number of contribution years.
} 
number of contribution years or having contributed to the pension fund continuously during a minimum number of years prior to early retirement. ${ }^{25}$ Due to stipulations in the Dutch tax law, early retirement benefits were generous and actuarially unfair. ${ }^{26}$ Early retirement benefits provided before normal retirement were higher than occupational pension benefits provided as of the normal retirement age to (partly) compensate early retirees for not receiving public old-age pension benefits before normal retirement.

\section{Regular early retirement arrangements for civil servants}

As of April $1^{\text {st }}, 1997$, early retirement benefits for civil servants consisted of two parts. The first part was in general 70 percent of the "franchise" for civil servants who had worked full-time during their working life. ${ }^{27}$ The first part intended to compensate early retirees for the lack of old-age pension benefits for the period between early retirement and normal retirement. Civil servants were eligible for the first part if they satisfied two conditions. First, they had to have been employed as civil servants continuously during the ten years prior to early retirement. Second, they had to have contributed continuously to the public pension fund during the ten years preceding early retirement. The first part of early retirement benefits, which was financed on a pay-as-you-go-basis, was in general higher when civil servants retired at later ages. Contributions for this part came from both workers and employers. Part two of early retirement benefits was funded. Workers and employers contributed to the accrual of benefits for this part. When civil servants would have accrued benefits for 40 years, the sum of the first and second part would have been 70 percent of workers' mid-career salaries. The replacement rate was reduced by 1.75 percentage points for every year civil servants would have accrued benefits less than 40 years. Civil servants were allowed to do paid work after early retirement. However, total income of retired civil

\footnotetext{
${ }^{25}$ For instance, early retirement arrangements of the public sector pension fund required workers to have contributed to the public pension fund continuously during the ten years prior to early retirement and to have contributed to the public sector pension system during 40 or more years, depending on the year of birth. We do not have access to data on occupational (early retirement) pensions.

${ }^{26}$ For individuals born before January 1,1950 , early retirement benefits are taxed, whereas premiums paid by workers and employers are exempted from taxation. As the income of workers is generally higher than that of early retirees, and as labor income is taxed at progressive rates, the marginal tax rate applying to the early retirement contribution by workers is often higher than the marginal tax rate applied to the early retirement benefits. This fact made early retirement very attractive for both eligible workers and employers. For individuals born on or after January 1, 1950, the tax advantage was abolished at the beginning of 2006 and early retirement arrangements for these individuals have disappeared in recent years.

${ }^{27}$ This replacement rate is based on retirement at the ER eligibility age. The ER eligibility age depends on the birth date of an individual.
} 
servants was not allowed to exceed 100 percent of the end-of-career salary. ${ }^{28}$ Otherwise, early retirement benefits were cut to bring down the total income earned to 100 percent of the end-of-career salary (means test).

\section{Other policy changes}

On January $1^{\text {st }}, 2004$, the public sector pension fund switched from an end-of-career salary pension system to a mid-career salary pension system. However, due to a transition arrangement, civil servants born before January $1^{\text {st }}, 1954$ were hardly affected by the switch.

\section{Early retirement via disability insurance}

Workers may be able to withdraw early from the labor force by starting to receive disability insurance (DI) benefits. Workers could start receiving DI benefits if they were judged to be disabled by a medical examiner of the social insurance institute. Depending on the extent of disability, DI benefits amounted to up to 75 percent of workers' end-of-career salaries. The duration of DI benefits was at least half a year with a maximum of six years. The DI system was financed by workers and employers. In the context of this paper, it is important to notice that civil servants faced the same generosity of and eligibility criteria for DI benefits as workers employed in other sectors, and that there were no major changes in DI in 2005 except one on December 29th.

From that day on, eligibility criteria for individuals starting to receive disability benefits have been tightened and disability benefits have been made less generous for workers who are only partially disabled. One year earlier, another change in disability insurance had taken place. From January $1^{\text {st }}$, 2004, workers could only start receiving DI benefits after having been continuously ill for two years while employed. We hardly observe any civil servants who are induced to retire in 2005 to start receiving disability benefits. Moreover, the inflow into DI for men in all ages decreased smoothly from 53,000 in 2001 to 36,000 in 2004 and dropped to 17,000 in 2005. It is thus unlikely that the retirement rates in 2005 were boosted by changed incentives in DI (Statistics Netherlands, 2006).

\footnotetext{
${ }^{28}$ Income does not only include wage income here, but also some other specified sources of income.
} 


\section{Tables and Figures}

Table 1: Descriptive statistics for couples that include a wife who was employed outside the public sector*

\begin{tabular}{|c|c|c|c|c|}
\hline \multirow[b]{3}{*}{ Variable } & \multicolumn{4}{|c|}{ Husband was employed as a civil servant } \\
\hline & \multicolumn{2}{|c|}{$\begin{array}{c}\text { Control group } \\
\text { Husband's ages 53-54 } \\
\text { Year } 2005\end{array}$} & \multicolumn{2}{|c|}{$\begin{array}{c}\text { Treatment group } \\
\text { Husband's ages 55-60 } \\
\text { Year } 2005\end{array}$} \\
\hline & Mean & Std. dev. & Mean & Std. dev. \\
\hline Wife's age & 54.05 & 1.32 & 55.70 & 1.95 \\
\hline Husband's age & 53.64 & 0.48 & 57.30 & 1.57 \\
\hline $\begin{array}{l}\text { Wage income wife [t-1] } \\
\text { (in 1000s of Euros) }\end{array}$ & 27.92 & 12.23 & 26.83 & 11.44 \\
\hline $\begin{array}{l}\text { Wage income husband [t-1] } \\
\text { (in 1000s of Euros) }\end{array}$ & 40.32 & 12.60 & 40.52 & 13.58 \\
\hline \multirow[t]{3}{*}{$\mathrm{N}$} & 329 & & 1,517 & \\
\hline & \multicolumn{4}{|c|}{ Husband was employed as a civil servant } \\
\hline & \multicolumn{2}{|c|}{$\begin{array}{l}\text { Husband's ages 53-54 } \\
\text { Years 2000-2004 }\end{array}$} & \multicolumn{2}{|c|}{$\begin{array}{l}\text { Husband's ages 55-60 } \\
\text { Years 2000-2004 }\end{array}$} \\
\hline Variable & Mean & Std. dev. & Mean & Std. dev. \\
\hline $\begin{array}{l}\text { Wife's age } \\
\text { Husband's age }\end{array}$ & $\begin{array}{l}54.14 \\
53.59\end{array}$ & $\begin{array}{l}1.39 \\
0.49\end{array}$ & $\begin{array}{l}55.56 \\
57.18\end{array}$ & $\begin{array}{l}1.86 \\
1.62\end{array}$ \\
\hline $\begin{array}{l}\text { Wife's wage income [t-1] } \\
\text { (in 1000s of Euros) }\end{array}$ & 26.49 & 11.20 & 26.43 & 11.62 \\
\hline $\begin{array}{l}\text { Husband's wage income [t-1] } \\
\text { (in 1000s of Euros) }\end{array}$ & 40.85 & 12.27 & 40.42 & 12.87 \\
\hline \multirow[t]{3}{*}{ N } & 1,077 & & 4,389 & \\
\hline & \multicolumn{4}{|c|}{ Husband was employed outside the public sector } \\
\hline & \multicolumn{2}{|c|}{$\begin{array}{l}\text { Husband's ages 53-54 } \\
\text { Years 2000-2005 }\end{array}$} & \multicolumn{2}{|c|}{$\begin{array}{l}\text { Husband's ages 55-60 } \\
\text { Years 2000-2005 }\end{array}$} \\
\hline Variable & Mean & Std. dev. & Mean & Std. dev. \\
\hline Wife's age & 54.18 & 1.44 & 55.62 & 1.90 \\
\hline Husband's age & 53.61 & 0.49 & 57.25 & 1.60 \\
\hline $\begin{array}{l}\text { Wife's wage income [t-1] } \\
\text { (in 1000s of Euros) }\end{array}$ & 26.62 & 11.12 & 26.55 & 11.43 \\
\hline $\begin{array}{l}\text { Husband's wage income [t-1] } \\
\text { (in 1000s of Euros) }\end{array}$ & 40.08 & 18.27 & 40.15 & 18.68 \\
\hline $\mathrm{N}$ & 8,669 & & 39,449 & \\
\hline
\end{tabular}

*The control group consist of wives employed outside the public sector whose husbands were employed as civil servants and aged 53 or 54 in 2005 . The treatment group consist of wives employed outside the public sector whose husbands were employed as civil servants and in the age category 55-60 in 2005. 
Table 2: Fixed effects uninstrumented estimates for the wife's probability to retire within one year *

\begin{tabular}{lc}
\hline $\mathrm{N}$ & 6,306 \\
$\begin{array}{l}\text { Coefficient estimate } \\
\text { retirement status husband }(\omega)\end{array}$ & -0.024 \\
$\begin{array}{l}\text { Standard error } \\
\text { P-value }\end{array}$ & 0.013 \\
& 0.075 \\
Fraction of total variation & 0.414 \\
$\begin{array}{l}\text { explained by individual fixed } \\
\text { effects }\end{array}$ &
\end{tabular}

Table 3: Fixed effects instrumental variable estimates for the wife's probability to retire within one year $*$

\begin{tabular}{lc}
\hline $\mathrm{N}$ & 6,306 \\
$\begin{array}{l}\text { Coefficient estimate } \\
\text { retirement status husband }(\widehat{\omega})\end{array}$ & 0.246 \\
$\begin{array}{l}\text { Standard error } \\
\text { P-value }\end{array}$ & 0.129 \\
& 0.057 \\
$\begin{array}{l}\text { F statistic on instruments in } \\
\text { first stage }\end{array}$ & 14.54 \\
$\begin{array}{l}\text { P-value } \\
\text { Fraction of total variation } \\
\text { explained by individual fixed } \\
\text { effects in first stage }\end{array}$ & 0.000 \\
$\begin{array}{l}\text { Fraction of total variation } \\
\text { explained by individual fixed } \\
\text { effects in second stage }\end{array}$ & 0.459 \\
\end{tabular}

*The model estimated here controls for wage income [t-1] of the husband and wife, year fixed effects, nonlinear husband's and wife's age effects and individual fixed effects. Standard errors are clustered at the individual level. 
Table 4: Robustness checks on functional form specification *

\begin{tabular}{|c|c|c|c|c|c|c|}
\hline Variation & & LATE & Std. err. & P-value & F stat. & $\mathbf{N}$ \\
\hline & $\begin{array}{l}\text { Baseline (Table 3): } \\
\text { FE IV 2nd, 3rd order age effects, year dummies, } \\
\text { individual fixed effects }\end{array}$ & 0.246 & 0.129 & 0.057 & 14.54 & 6,306 \\
\hline a. & FE IV 2nd order age effects & 0.260 & 0.141 & 0.064 & 9.87 & 6,306 \\
\hline b. & FE IV 2nd, 3rd, 4th order age effects & 0.224 & 0.124 & 0.071 & 12.69 & 6,306 \\
\hline c. & FE IV age dummies & 0.240 & 0.125 & 0.055 & 13.02 & 6,306 \\
\hline d. & FE IV 1st, 2nd, 3rd order year effects & 0.241 & 0.124 & 0.052 & 8.63 & 6,306 \\
\hline e. & Random effects IV (baseline sample) & 0.256 & 0.085 & 0.003 & 42.49 & 6,306 \\
\hline f. & Pooled IV (baseline sample) & 0.261 & 0.122 & 0.032 & 16.46 & 6,306 \\
\hline
\end{tabular}

*The model estimated here controls for wage income [t-1] of the husband and wife, year fixed effects, nonlinear husband's and wife's age effects and individual fixed effects, unless mentioned otherwise. The models estimated in variations e and f control for husband's and wife's birth year fixed effects as well. The LATEs refer to the coefficient estimates for retirement status of the husband ( $\widehat{\omega})$. Standard errors are clustered at the individual level, except the ones in variation e. In variation e, we use bootstrapped standard errors that are based on 200 replications). 
Table 5: Robustness checks on data selection *

\begin{tabular}{|c|c|c|c|c|c|c|}
\hline Variation & & LATE & Std. err. & P-value & F stat. & $\mathbf{N}$ \\
\hline & $\begin{array}{l}\text { Baseline (Table 3): } \\
\text { FE IV; data selection: husbands, wives: age category 53-60, wage } \\
\text { income [t-1] of at least 15,000 euros per year, employment tenure } \\
\text { of at least } 10 \text { years, not hospitalized between } 1999 \text { and the final } \\
\text { year of observation, did not die in the year of observation, married } \\
\text { for at least } 5 \text { years; wives: employed outside the public sector, } \\
\text { husbands: employed as civil servants }\end{array}$ & 0.246 & 0.129 & 0.057 & 14.54 & 6,306 \\
\hline a. & FE IV for dataset incl. workers aged 52 & 0.233 & 0.108 & 0.031 & 18.50 & 8,142 \\
\hline b. & FE IV for dataset incl. workers without Dutch citizenship & 0.252 & 0.128 & 0.049 & 15.07 & 6,888 \\
\hline c. & $\begin{array}{l}\text { FE IV for dataset incl. workers earning a wage income [t-1] of } \\
10,000-14,999 \text { euros per year }\end{array}$ & 0.213 & 0.120 & 0.077 & 17.69 & 8,484 \\
\hline d. & $\begin{array}{l}\text { FE IV for dataset excl. workers earning a wage income [t-1] of } \\
15,000-19,999 \text { euros per year }\end{array}$ & 0.323 & 0.151 & 0.030 & 14.48 & 4,035 \\
\hline e. & $\begin{array}{l}\text { FE IV for dataset incl. workers hospitalized between } 1999 \text { and the } \\
\text { final year of observation }\end{array}$ & 0.124 & 0.090 & 0.168 & 19.35 & 8,751 \\
\hline f. & FE IV for dataset incl. workers married $1-4.99$ years & 0.208 & 0.128 & 0.104 & 14.81 & 6,420 \\
\hline g. & FE IV for dataset excl. workers married 5-9.99 years & 0.245 & 0.136 & 0.071 & 13.70 & 5,699 \\
\hline h. & FE IV for dataset incl. husbands employed outside the public sector & 0.291 & 0.106 & 0.006 & 9.31 & 50,589 \\
\hline
\end{tabular}

*The model estimated here controls for wage income [t-1] of the husband and wife, year fixed effects, nonlinear husband's and wife's age effects and individual fixed effects. The LATEs refer to the coefficient estimates for retirement status of the husband ( $\widehat{\omega})$. Standard errors are clustered at the individual level. 
Table 6: First and second stage estimates (underlying the baseline specification of Table 3)

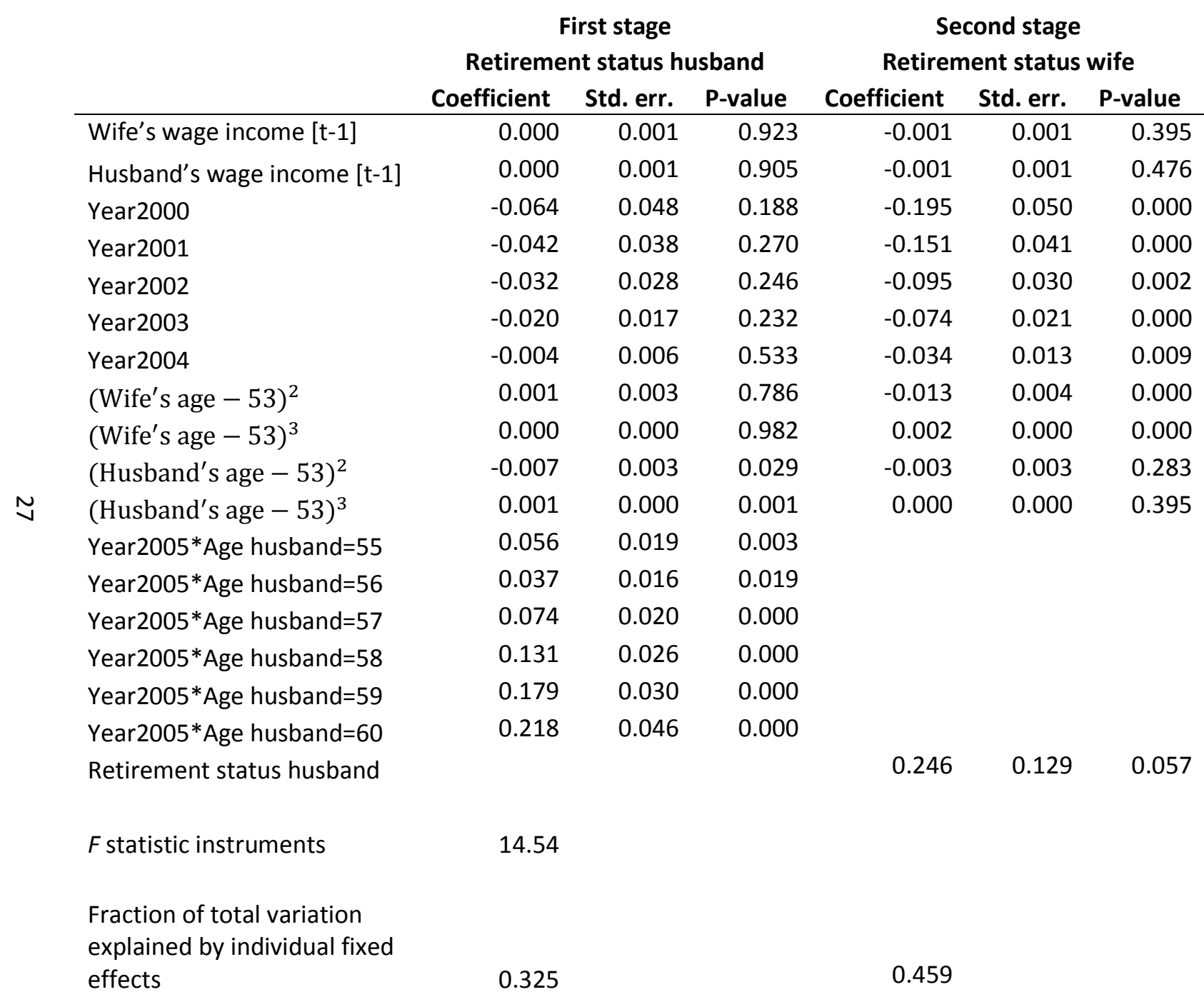


Figure 1: Retirement rates for husbands employed as civil servants, by husbands' birth cohort (percentages)*

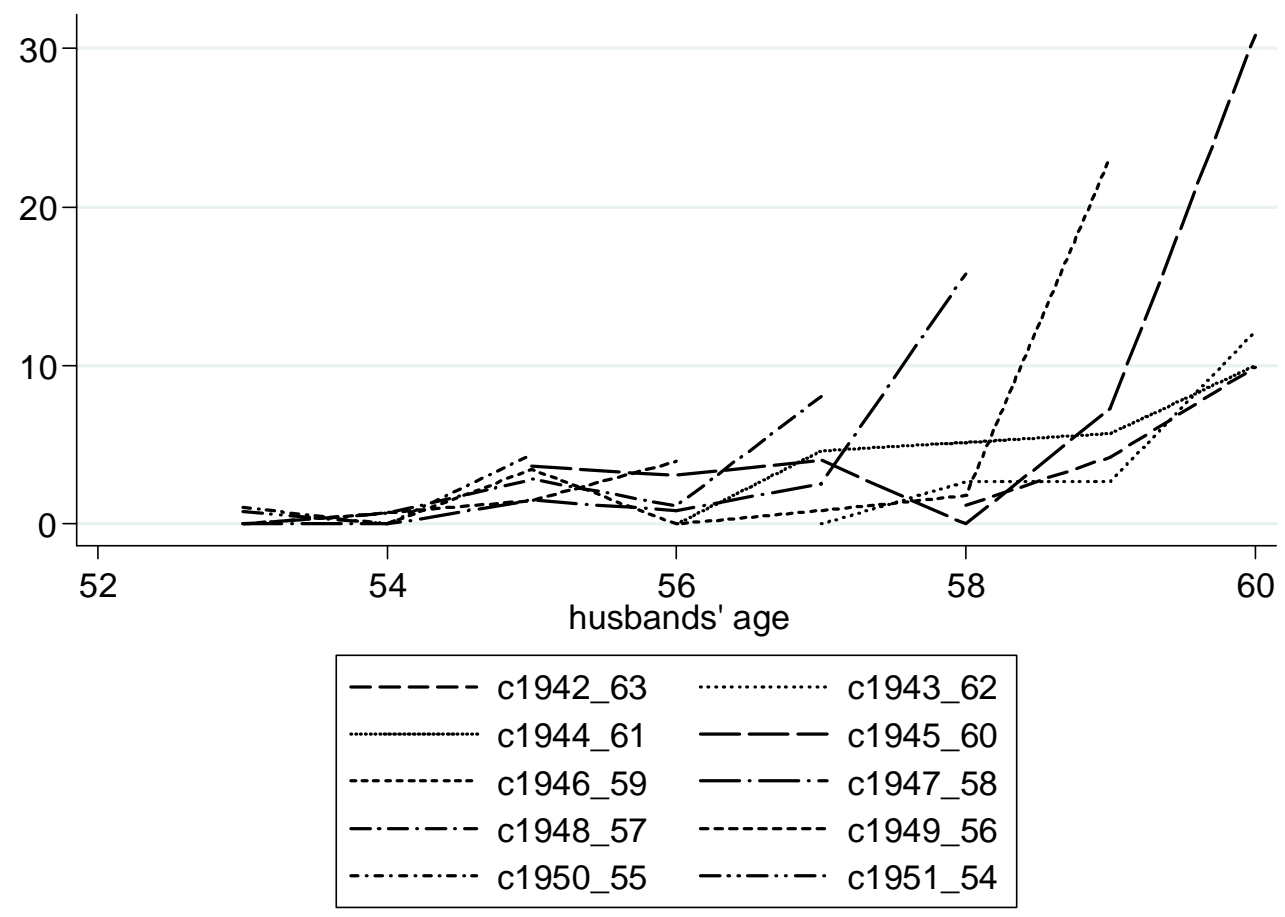

*Husbands' age on December $31^{\text {st }}, 2005$ is indicated behind each birth cohort. This figure is based on data for the period 2000-2005. 
Figure 2: Retirement rates for husbands employed outside the public sector, by husbands' birth cohort (percentages)*

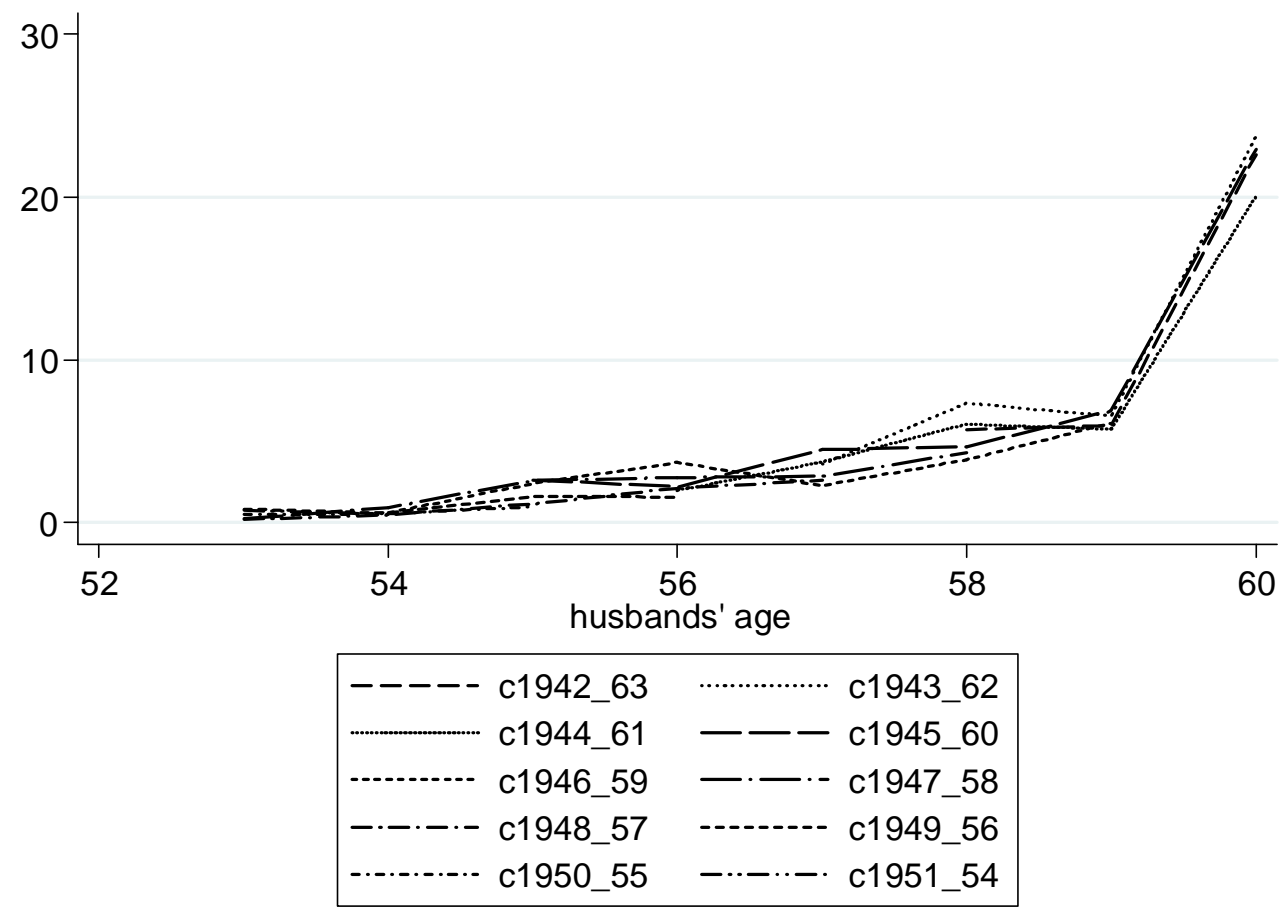

*Husbands' age on December $31^{\text {st }}, 2005$ is indicated behind each birth cohort. This figure is based on data for the period 2000-2005. 
Figure 3: Retirement rates for wives employed outside the public sector with husbands employed outside the public sector as well, by husbands' birth cohort (percentages)*

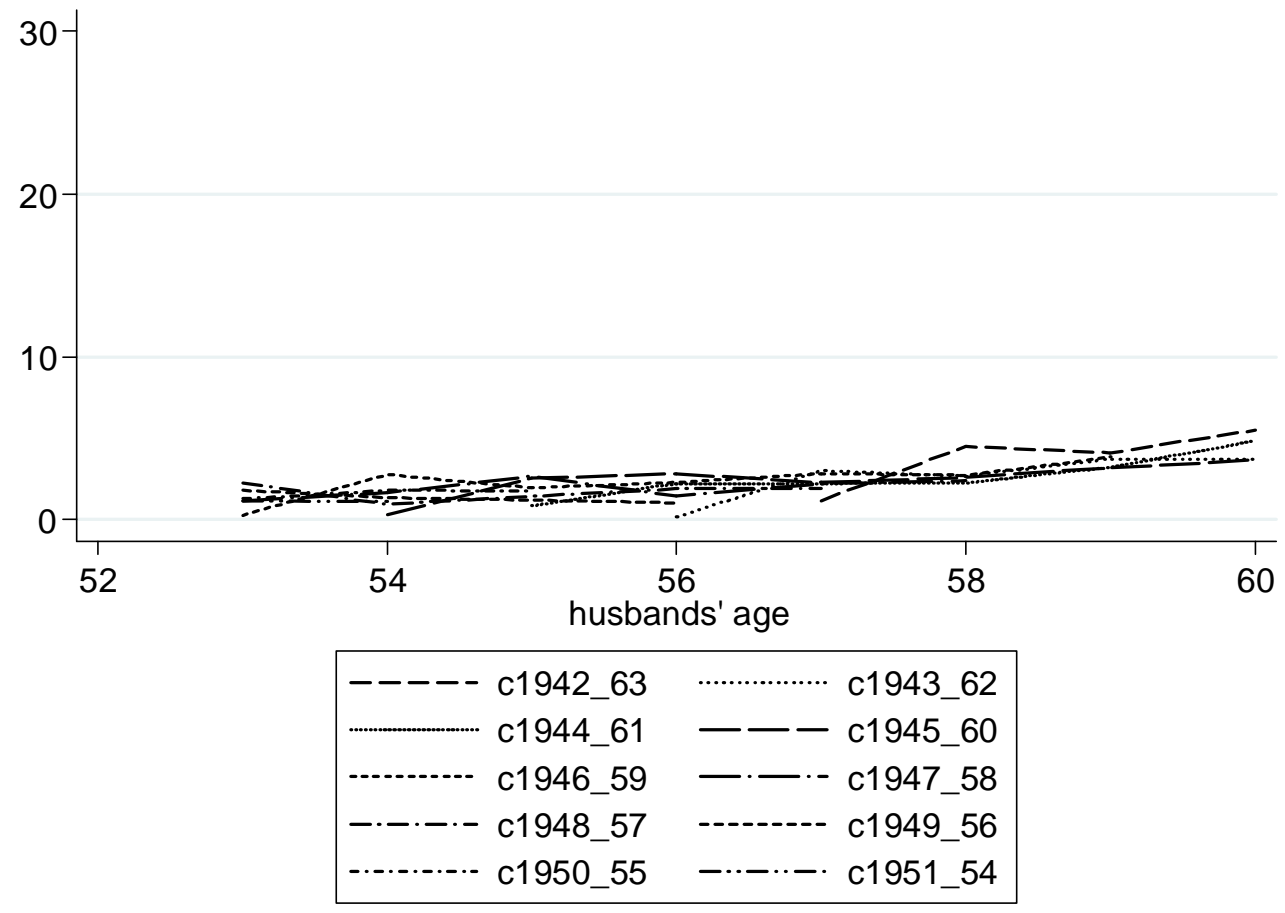

*Husbands' age on December $31^{\text {st }}, 2005$ is indicated behind each husbands' birth cohort. This figure is based on data for the period 2000-2005. 
Figure 4: Retirement rates for wives employed outside the public sector with husbands employed as civil servants, by husbands' birth cohort (percentages)*

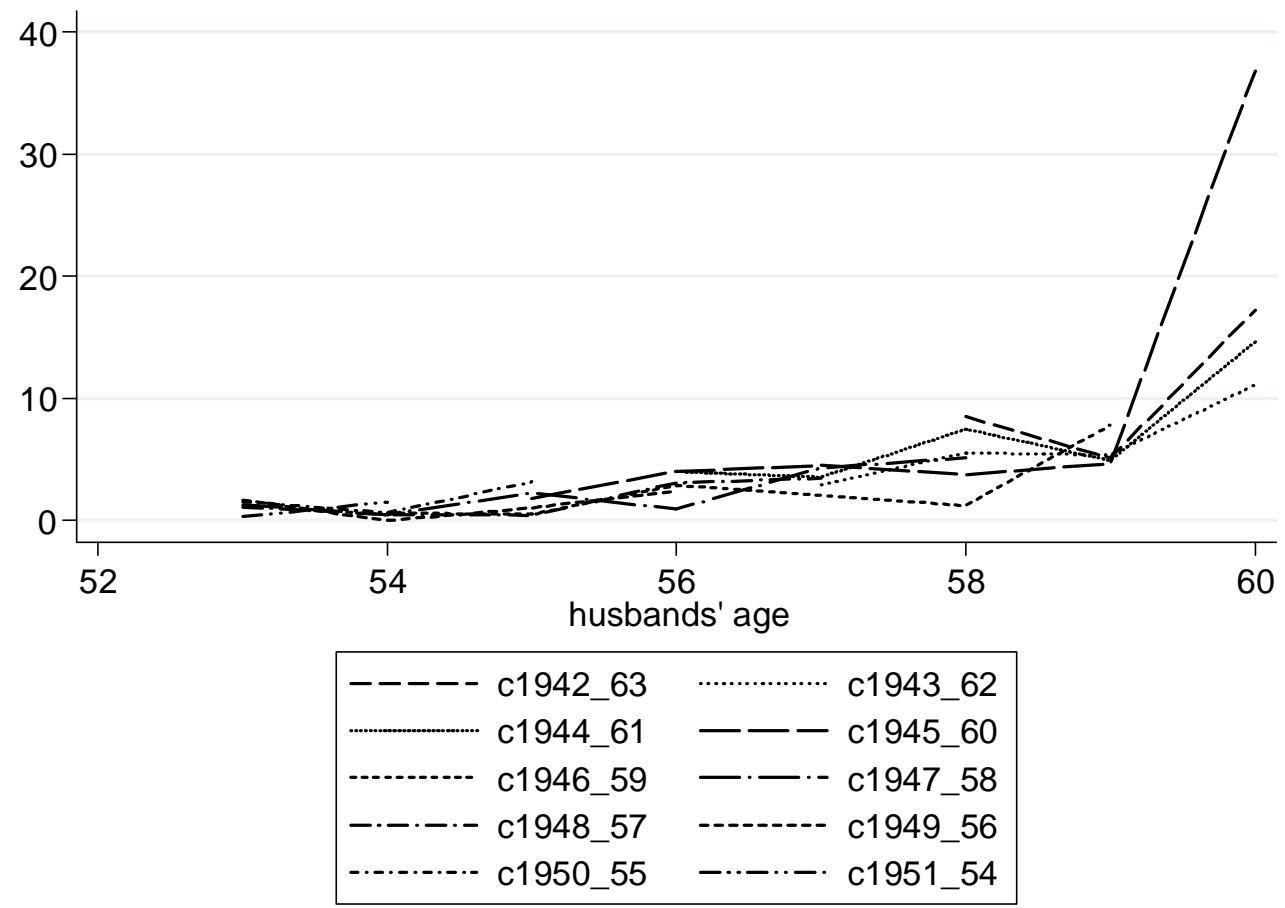

*Husbands' age on December $31^{\text {st }}, 2005$ is indicated behind each husbands' birth cohort. This figure is based on data for the period 2000-2005. 